\title{
Ário Dídimo, Epítome de ÉTICA \\ EstoicA, 2.7.5A- 2.7.5B ${ }^{1}$
}

\author{
Rodrigo Pinto de Brito ${ }^{2}$ \\ Aldo Dinucci ${ }^{3}$
}

RESUMO: Tradução dos passos 2.7.5A- 2.7.5B da Epitome de Ética Estoica, do filósofo estoico e doxógrafo alexandrino Ário Dídimo (acme 30 a.C.). Nâo há traduçôes em língua moderna das obras completas de Ário Dídimo. Assim, para esta tradução, usamos a fixação da exposição sobre a ética estoica presente em Estobeu (Florilégio), realizada por Pomeroy (1999). A seção que traduzimos versa sobre o conceito estoico de excelência, explicando o que ela é, quais as virtudes que dela participam, e como. Por antítese, Ário Dídimo também elucida o conceito estoico de vício, o que ele é e qual a sua taxonomia.

PALAVRAS-CHAVE: Filosofia helenística. Ética estoica. Ário Dídimo. Tradução.

\section{INTRODUÇÁO}

Ário Dídimo foi um filósofo e um doxógrafo alexandrino estoico de tendência eclética, simpático à Academia (sobretudo Antioco de Ascalón ${ }^{4}$, Eudoro de Alexandria ${ }^{5}$ e Filo de Larissa ${ }^{6}$ ). Seus fragmentos foram organizados por Diels (1879, p. 445-472). Estobeu cita-o verbatim em suas Éclogas. Não há edição completa em língua moderna de sua obra, embora haja uma versão em inglês do texto que aqui traduzimos, em parte, aquela de Pomeroy (1999). Para a presente tradução, usamos a fixação do texto realizada por Pomeroy, o

\footnotetext{
${ }^{1}$ Trabalho realizado sob auspícios da University of Kent - Canterbury/UK, como resultado parcial de pesquisa de Pós-Doutorado, PGCI 041/14- CAPES.

http://dx.doi.org/10.1590/S0101-317320160002000013

${ }^{2}$ Professor adjunto do DFL/UFS; Doutor em Filosofia pela PUC-RJ. Membro dos grupos de pesquisa ARCHAI e Viva Vox. Editor júnior da Prometeus Filosofia. E-mail: www.rodrigobrito@gmail.com

${ }^{3}$ Professor associado do DFL/UFS; Doutor em Filosofia pela PUC-RJ. Membro dos grupos de pesquisa ARCHAI e Viva Vox. Editor responsável da Prometeus Filosofia. E-mail: aldodinucci@yahoo.com.br

${ }^{4}$ Filósofo eclético que viveu entre 130 e 68 a. C. Tentou conciliar o estoicismo, o platonismo e o aristotelismo.

${ }^{5}$ Floresceu por volta de 40 d.C. e defendeu um neoplatonismo eclético.

${ }^{6}$ Filósofo eclético que viveu entre 154/3-84/3 a.C. e foi um dos líderes da Academia.
} 
qual, por sua vez, apoiou-se na edição de Wachsmuth e Hense das Éclogas de Estobeu. Quanto aos pressupostos e premissas de nosso trabalho, partimos da suposição de que Ário apresenta o que considera ser a concepção ortodoxa da ética estoica. Tal suposição apoia-se no próprio texto de Ário, que tem como título "As opiniôes de Zenáo e do restante dos estoicos sobre a parte ética da filosofia”, que é seguido pela frase "[...] far-se-á um memorando sobre a ética, considerando as principais e mais necessárias opiniōes". Nesse caso, pareceu-nos acertado escolher para os termos técnicos traduçóes condizentes com a ortodoxia estoica, o que efetivamente fizemos ${ }^{7}$. Os principais termos técnicos são apresentados transliterados em notas, na medida em que ocorrem no texto. Com isso, buscamos guiar o trabalho de exegese conceitual do leitor, bem como evidenciar nosso procedimento de unificação, na tradução dos conceitos. É importante acrescentar que temos por método evitar todo tipo de paráfrase. Buscamos também preservar, na tradução, sempre que possível, a estrutura sintática do texto grego original.

Pouco sabemos sobre sua vida, mas somos informados, por duas notas em manuscritos, que o livro VII da Vida dos Filósofos Ilustres, de Diógenes Laércio, continha originalmente relato biográfico sobre certo "Arius", provavelmente Ário Dídimo (DIELS, 1879, V. 1, P. 81) ${ }^{8}$.

Pelos historiadores antigos, sabemos que Ário foi amigo e conselheiro de Augusto, a partir de 30 a.C. Augusto a tal ponto o admirava, que poupou Alexandria da destruição, após sua vitória na batalha de Actium, por ser a cidade natal do filósofo. (DÍON CÁSSIO, LI, 16, 3-4; PLUTARCO, Antônio, 80; JULIANO, Carta 51, 433d; SÊNECA, Consolação a Márcia, 4-5). Suetônio (Augusto, 89.1) nos informa os nomes de dois filhos de Ário: Nicanor e Dioniso.

Aparentemente, Ário publicou uma só obra filosófica em vida, cujo título não nos chegou. Tal obra, que é chamada por Estobeu (Éclogas, 2.1.17), ora de Sobre as Escolas, ora de Epitome (Éclogas, 4.39), teria seção intitulada Sobre as doutrinas de Platão (DIELS, Fragmento 1 (= Eusébio, P.E., XI, 15.9). Fragmentos de Ário tratando de Xenófanes em Estobeu (Éclogas, 2.1.17), bem como de seção concernente a Pitágoras (CLEMENTE DE ALEXANDRIA,

\footnotetext{
${ }^{7}$ Nisso fomos auxiliados pelo excelente glossário da tradução de Pomeroy.

${ }^{8}$ Diels (1879, p. 69-88) nos oferece um relato biográfico de Ário. Outros estudos contemporâneos sobre a vida de Ário são: Fraser, 1972, v. 1, p. 489-491; Glucker, 1978, p. 94-97.
} 
Stromata, 1.16.80.4) ${ }^{9}$ e ainda referências de Ário a filósofos anteriores a Platão em Clemente de Alexandria (Stromata, 1.14.61; 1.16.80 - Cf. HAHM, 1990, p. 12, nota 5), indicam a amplitude de tal obra.

Entretanto, é possível que tal trabalho se confunda com o relato doxográfico a ele atribuído, do qual nos chegaram fragmentos da física e da ética, bem como traços de uma seção sobre lógica (HAHM, 1990, p. 15) ${ }^{10}$. Tal obra provavelmente se compunha de capítulos sobre as escolas, divididos em seções sobre física, ética e lógica.

A exposição acerca da ética estoica, constante no segundo livro do Florilégio de Estobeu, é a mais minuciosa que nos chegou, intimamente relacionada àquelas de Cícero (De finibus, 3.16.76) e Diógenes Laércio (Vidas dos Filósofos Ilustres, 7.84-131), pelo que se sustenta que todas derivam de uma única fonte (VON ARNIM, Stoicorum Veterum Fragmenta, doravante $S V F, 1903-05$, v. 1, p. xxx-xliii). Giusta (1964-7) empreendeu uma pesquisa, mostrando a unidade dos três relatos, que Long (1983, p. 107), embora elogiando o trabalho acadêmico, critica por obscurecer o que os distingue.

Quanto à autoria da obra hoje atribuída a Ário e presente em Estobeu, é apoiada pela evidência observada por Meineke (1859, p. 364; Cf. DIELS, 1879 , p. 69), que percebeu uma repetição de parágrafos em Estobeu II e IV, tratando das fontes da eudaimonía, que, em um único códice do texto de Estobeu IV, recebe, como subtítulo, "Do epítome de Ário". Tal evidência é aceita por H. Diels (1879, p. 69) e Hahm (1990). Posteriormente posta em dúvida por Görinnsson (1995), foi reafirmada por Inwood (1995a), sendo hoje aceita.

\section{QUADRO SINÓPTICO}

Em [2.7.5.1], temos a clássica distinção estoica entre coisas boas, más e indiferentes (CÍCERO, De finibus 3.33). O parágrafo se inicia com a afirmação, atribuída a Zenão de Cítio ${ }^{11}$, que "[...] das coisas, umas quantas participam da substância” (ousía). Quanto a isso, Pomeroy (1999, p. 105, n. 3) observa que a

\footnotetext{
${ }^{9}$ Clemente refere-se a uma obra de Ário sobre pitagorismo, mas o mais provável é que seja outra seção da obra perdida.

${ }^{10}$ Ressaltamos que física, lógica e ética são consideradas as partes em que, desde os primórdios do estoicismo (Zenão de Cítio), a filosofia se dividiria.

${ }^{11}$ Zenão de Cítio, fenício fundador do estoicismo e primeiro escolarca do Pórtico Ateniense, viveu entre 334 a.C. e 262 a.C.
} 
afirmação se relaciona ao fato de que, no estoicismo, excelências e vícios existem fisicamente (como impulsos), pelo que participam da substância (corpórea) e afetam causalmente, produzindo atos bons (SÊNECA, Cartas a Lucílio, 117.2).

Em [2.7.5b.1], Ário estabelece uma ulterior distinção entre as coisas boas: as que são excelências e as que participam das excelências (não é expresso no texto, mas podemos assegurar que atos bons e bons sentimentos, por serem causados pela excelência, estão entre as coisas que participam dela).

Em [2.7.5b.5], Ário distingue entre excelências que são conhecimentos e técnicas e aquelas que não o são.

Em [2.7.5b.10], Ário faz distinçôes análogas à dos bens acerca dos males, que se dividem entre os que são vícios e os que participam dos vícios (não é expresso no texto, mas podemos afirmar que maus atos e maus sentimentos, por serem causados pelo vício, estão entre as coisas que participam dele). E discerne também, entre os vícios, os que são ausência de conhecimento e de técnica e os que não o são.

Em [2.7.5b1.1], temos as definiçôes das principais excelências.

Em [2.7.5b.1.10], as definiçôes dos principais vícios.

Em [2.7.5b1.15], é-nos oferecida uma definição geral de excelência (cf. comentário mais abaixo a [2.7.5b3.1-5]).

Em [2.7.5.b2.1], Ário trata das excelências primárias e daquelas que lhes são derivadas. As primárias apresentadas por Ário correspondem às "virtudes cardeais" (cf. abaixo, nota 56).

Em [2.7.5b2.10], o alexandrino enumera as excelências derivadas daquelas, definindo-as.

Em [2.7.5b3.1-5], Ário volta à definição da excelência.

Em [2.7.5b1.15], já frisara que "[...] a <excelência> é a disposição da alma harmonizada consigo mesma no que concerne à totalidade da vida”. Agora, assevera que o fim da excelência é viver segundo a natureza e que, "[...] segundo o harmonioso, cada uma dessas excelências por si mesma confere ao homem a vida seguindo a natureza”.

Entre [2.7.5b4.1] e [2.7.5b4.15], Ário menciona excelências não técnicas, as quais são capacidades que se desenvolvem pelo exercício. 
Em [2.7.5b5.1], temos a afirmação da unidade das excelências, acompanhada, em [2.7.5b5.5], da asserção sobre o que as distingue quanto às funções.

$\mathrm{Na}$ sequência, em [2.7.5b7.1], o alexandrino aborda a excelência em relação à alma humana, sendo, como a alma, corpórea e viva.

Em [2.7.5b8.1], temos a tese estoica ortodoxa segundo a qual não há gradação entre o sábio e o tolo, pois ou alguém é sábio ou é tolo.

Em [2.7.5b9.1], é apresentada a clássica discussão da relação entre o amor e o sábio, sob o ponto de vista do estoicismo.

Em [2.7.5b10.1], temos a tese de acordo com a qual o sábio tudo bem realiza.

Em [2.7.5b10.10], a tese contrária, segundo a qual o medíocre tudo faz mal.

A apresentação de Ário é minuciosa. No seu desenvolvimento das taxonomias, o alexandrino utiliza a metodologia estoica, sobretudo o procedimento diairético (diaíresis) (DIÓGENES LAÉRCIO, VII, 7.98), pelo qual um gênero é subdividido em suas espécies (como a divisão das excelências e dos vícios) e o método antidiairético (antidiairesis) (DIÓGENES LAÉRCIO, VII, 7.98), pelo qual um gênero é subdividido em contrários (como a célebre distinção entre coisas boas, más e indiferentes).

\section{Traduçấo}

\subsubsection{1 <As opinióes ${ }^{12}$ de Zenáo e do restante dos estoicos sobre a parte ética da filosofia.>}

A seguir, far-se-á um memorando sobre a ética, considerando-se as principais e mais necessárias opiniôes. Que se comece, entấo.

\footnotetext{
12 "Opinião" aqui traduz o termo grego dógma. A noção tem uma conotação ampla, no estoicismo, designando desde o que chamamos hoje de mera opiniáo (um parecer não qualificado sobre algo) quanto princípios filosoficamente estabelecidos e defendidos concernentes à realidade das coisas, o que é aqui o caso. A tradução "dogma" não nos parece adequada, pois o termo atualmente tem forte conotaçâo religiosa, indicando, na maioria das vezes, um princípio teológico obtido por "revelação" e nâo pela razão, enquanto, em sua acepção geral, o termo técnico estoico dógma indica o contrário: uma apreensão racional - katálēpsis logikế. Cf. SVF II.121 (= CLEMENTE, Stromata, VIII.5); SVF III.278 (= ESTOBEU, Éclogas II.62.15); SVF III.474).
} 
[2.7.5a.1] Do que existe, diz Zenão, umas quantas coisas participam da substância ${ }^{13}$; das coisas existentes, algumas são $\left\langle\right.$ boas $\left.^{14}\right\rangle$, outras $\left\langle\right.$ más $\left.^{15}\right\rangle$, outras <indiferentes ${ }^{16}$. Boas> são tais: prudência ${ }^{17}$, temperança ${ }^{18}$, justiça ${ }^{19}$, coragem $^{20}$ e tudo que é excelência ou participa da excelência.

[2.7.5a.5] Más são tais: imprudência ${ }^{21}$, intemperança $a^{22}$, injustiça ${ }^{23}$, covardia $^{24}$ e tudo o que é vício ou participa do vício; indiferentes são tais: vida e morte, prestígio e desprestígio, prazer e dor, riqueza e pobreza, saúde e doença, e coisas semelhantes a essas.

[2.7.5b.1] Das coisas <boas >, algumas são <excelências >, outras <não.> Portanto, por um lado, a prudência, a temperança, $<$ a justiça, $>$ a coragem, $<$ a grandeza de alma ${ }^{25}$, a força ${ }^{26}$ e o poder ${ }^{27} \mathrm{da}$ alma $>$ são <excelências; $>$ por outro lado, o júbilo ${ }^{28}$, a alegria ${ }^{29}$, a confiança ${ }^{30}$, o desejo ${ }^{31}$ e coisas semelhantes <não> são excelências.

[2.7.5b.5] Das <excelências>, algumas são $<$ conhecimentos $^{32}>\mathrm{e}$ $<$ técnicas $^{33}>$ de certas coisas, outras não. Assim, por um lado, prudência,

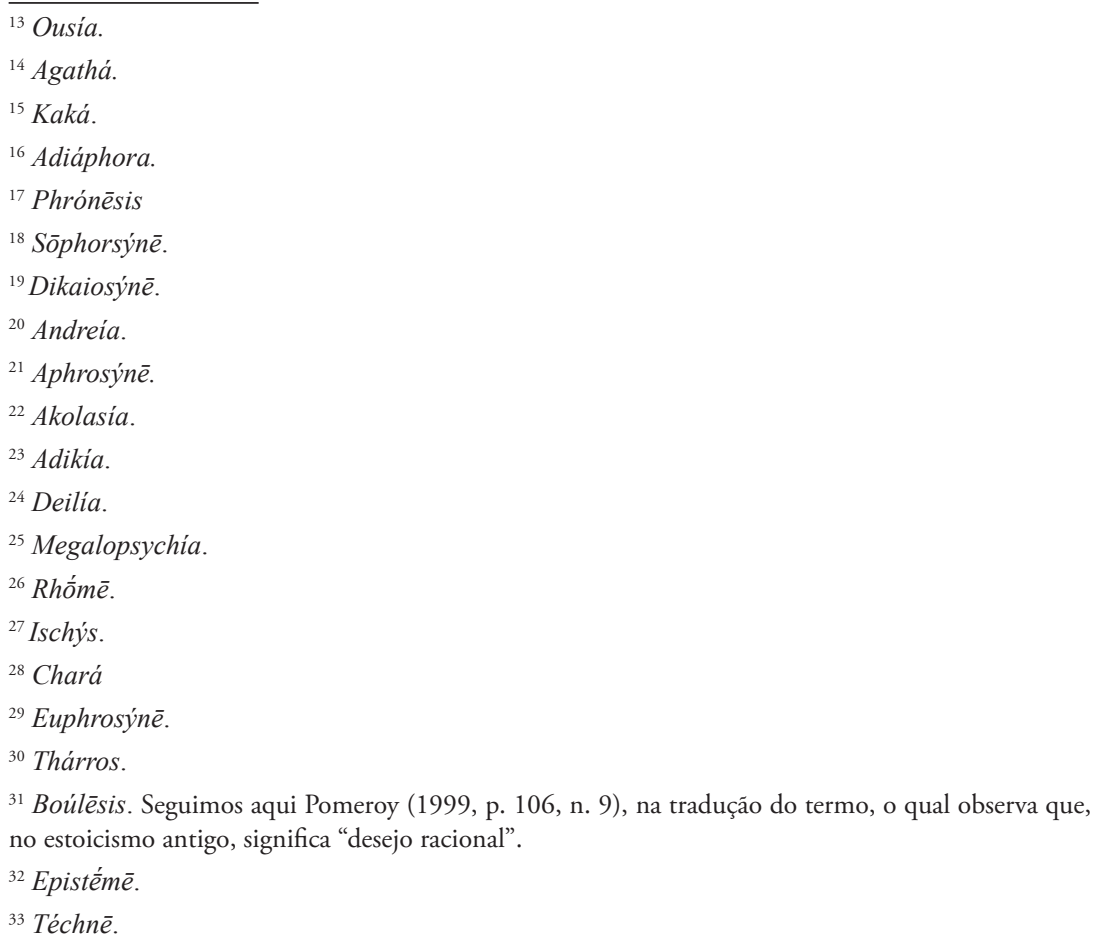


temperança, justiça e coragem são <conhecimentos $>$ e $<$ técnicas $>$ de certas coisas; por outro lado, grandeza de alma, força e poder da alma nem são tipos de $<$ conhecimento $>$, nem de $<$ técnicas. $>$

[2.7.5b.10] De modo análogo, das coisas <más>, algumas são <vícios,> outras < não. $>$ Com efeito, por um lado, a imprudência, a injustiça, a covardia, a pequenez de alma ${ }^{34}$ e a impotência ${ }^{35}$ são <vícios >; por outro lado, a dor, o medo e [coisas] semelhantes <não $>$ são vícios. Dos vícios, alguns são tipos de $<$ ausência de conhecimento ${ }^{36}>$ e de <ausência de técnica ${ }^{37}>$, outros <não.>

[2.7.5b.15] Assim, por um lado, imprudência, intemperança, injustiça e covardia são tipos de <ausência de conhecimento > e de <ausência de técnica >; por outro lado, pequenez de alma, impotência $<$ e fraqueza ${ }^{38}><$ nem são $>$ tipos $<$ de ausência de conhecimento $>$, nem $<$ de ausência de técnica $>$.

[2.7.5b1.1] < Prudência> é conhecimento do que é preciso fazer, do que é preciso não fazer ${ }^{39} \mathrm{e}$ dos neutros, ou o conhecimento dos bens e dos males e dos neutros do animal por natureza <racional> e político. E, quanto ao restante das excelências, desse mesmo modo transmitem [o que é preciso] ouvir.

[2.7.5b1.5] < Temperança> é conhecimento do que é preciso escolher e evitar e dos neutros; <justiça>, conhecimento da distribuição do que é merecido a cada um; <coragem $>$, conhecimento das coisas que amedrontam, das que não amedrontam e das neutras; <imprudência é> <ignorância> dos bens, dos males e dos neutros, ou ignorância do que é preciso fazer, do que é preciso não fazer e dos neutros.

[2.7.5b1.10] <Intemperança é> ignorância do que é preciso escolher e evitar e dos neutros; <injustiça é> ignorância da não distribuição do que é merecido a cada um>; <covardia é> ignorância do que amedronta e do que não amedronta e dos neutros. Igualmente também as outras excelências e vícios se definem, mantendo o que foi dito.

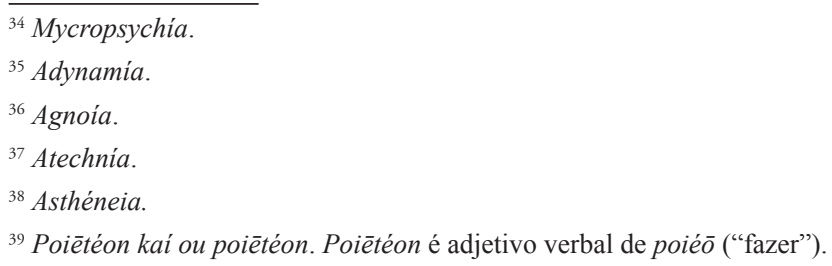


[2.7.5b1.15] Comumente, dizem que a <excelência> é a disposição harmoniosa ${ }^{40} \mathrm{da}$ alma consigo mesma, no que concerne à totalidade da vida.

[2.7.5.b2.1] Das <excelências>, algumas são <primárias>, outras às primárias < são subordinadas; as primárias $>$ são quatro, prudência, temperança, coragem e justiça ${ }^{41}$. E a $<$ prudência $>$ concerne aos atos convenientes ${ }^{42}$.

[2.7.5b2.5] A <temperança> concerne aos impulsos ${ }^{43}$ do homem; a $<$ coragem> concerne à resistência; a <justiça > concerne à distribuição. Das excelências derivadas dessas, algumas derivam da prudência, algumas da temperança, outras da coragem e outras ainda da justiça.

[2.7.5b2.10] Portanto, da <prudência> são derivados bom juízo ${ }^{44}$, circunspecção $^{45}$, sagacidade ${ }^{46}$, bom-senso ${ }^{47},<$ perspicácia $^{48}>$, inventividade ${ }^{49}$; da $<$ temperança $>$, disciplina ${ }^{50}$, compostura ${ }^{51}$, dignidade ${ }^{52}$, autocontrole ${ }^{53}$;

40 "Harmoniosa" traduz sýmphonos.

${ }^{41}$ As "virtudes cardeais". (PLATÃO, República, IV, 426-435; Protágoras, 330 b).

${ }^{42}$ Tó kathékon: termo técnico estoico forjado por Zenão de Cítio, que significa "ação conveniente", "ação conforme à natureza" (Cícero o traduz por officium; Sêneca, por convenientia). A esse conceito relaciona-se tó katothốrma, que é ação perfeita, o kathếkon realizado pelo sábio. (SVF III.491).

${ }^{43}$ Hormèe, "impulso", termo técnico que designa o movimento primeiro da alma que, visando a algo, leva à ação (SVF II.458; III.169; III.377). O termo pode tanto indicar o impulso que se origina espontaneamente da própria natureza antes do assentimento (como no caso do medo diante de algo que ameaça a existência) quanto o impulso que já recebeu o assentimento por parte da faculdade diretriz. Entretanto, deve-se frisar que, no estoicismo, o impulso propriamente dito (e que leva infalivelmente à ação) é aquele assentido pela mente, pois o outro, embora originado da natureza instintiva do homem, precisa desse assentimento para efetivamente causar uma ação (IOPOLLO, 1987, p. 460). Neste sentido último, é a razão que leva alguém a agir (SVF III.175) ou, como o define Inwood (1985b, p. 62), "[...] uma ordem dada a si mesmo que é obedecida".

${ }^{44}$ Eubolía.

${ }^{45}$ Eulogistía.

${ }^{46}$ Anchínoia.

${ }^{47}$ Nounéchia.

${ }^{48}$ Eustochía.

${ }^{49}$ Eumēchanía.

${ }^{50}$ Eutaxia.

${ }^{51}$ Kosmiótēta.

${ }^{52}$ Aidèmosýnē. Termo derivado de aidốs, de difícil tradução, que designa não somente a capacidade de envergonhar-se moralmente, mas também a reserva e a modéstia.

${ }^{53}$ Enkráteia. 
da <coragem>, perseverança ${ }^{54}$, bravura ${ }^{55}$, grandeza de alma ${ }^{56}$, bom ânimo ${ }^{57}$, industriosidade ${ }^{58} ;$ [2.7.5b2.15] da <justiça>, piedade ${ }^{59}$, honestidade ${ }^{60}$, companheirismo $^{61}$, tratamento justo ${ }^{62}$. De fato, <bom juízo $>$ é, dizem, conhecimento do tipo de ações a executar e como <executá-las> proveitosamente; <circunspecção $>$, conhecimento balanceado e sumarizado do <que está em $>$ devir e $<$ do que está $>$ completo.

[2.7.5b2.20] <Sagacidade>, conhecimento que descobre a ação imediatamente apropriada; <bom-senso $>$, conhecimento do pior e do melhor; <perspicácia, conhecimento > do vantajoso <para> cada escopo; $<$ inventividade>, conhecimento que descobre uma passagem pelos problemas; $<$ disciplina $>$, conhecimento de quando algo deve ser feito e o que, sobretudo, de modo geral, é a ordem das açóes.

[2.7.5b2.25] <Compostura>, < conhecimento> dos movimentos adequados e dos inadequados; <modéstia $>$, conhecimento que cuida de evitar a reta censura; <autocontrole>, conhecimento da não transgressão ao que aparece de acordo com a reta razão; <perseverança>, conhecimento disposto a persistir no corretamente julgado.

[2.7.5b2.30] <Bravura $>$, conhecimento por meio do qual sabemos que nada terrível encontraremos; <grandeza de alma>, conhecimento sobre o que é por natureza produzido, seja bom ou mau.

[2.7.5b2.35] <Bom ânimo $>$, conhecimento da alma demonstrada ela própria inexpugnável; <industriosidade>, conhecimento capaz de cumprir o proposto, não evitando o labor; <piedade>, conhecimento dos serviços aos deuses; <honestidade>, conhecimento da boa ação; <companheirismo>, conhecimento da igualdade na comunháo.

[2.7.5b2.40] < Tratamento justo>, conhecimento de [como] relacionarse de modo irrepreensível com o próximo.

\footnotetext{
${ }^{54}$ Kartería.

${ }^{55}$ Tharraleótēta.

${ }^{56}$ Megalopsychí.

${ }^{57}$ Eupsychía.

${ }^{58}$ Philoponía.

${ }^{59}$ Eusébeia.

${ }^{60}$ Chēstótēta.

${ }^{61}$ Eukoinōnēsía.

${ }^{62}$ Eusynallaxía.
} 
[2.7.5b3.1] $\mathrm{O}$ fim $^{63}$ de todas essas excelências é viver seguindo a natureza $^{64}$; <cada> uma delas, através das suas peculiaridades, permite ao homem atingir <esse fim $>$. Pois, por natureza, $<$ o homem $>$ tem um ponto de partida para a descoberta da ação conveniente, para a estabilidade ${ }^{65}$ dos impulsos, para a persistência e para a partilha.

[2.7.5b3.5] E, segundo o harmonioso, cada uma dessas excelências confere ao homem, por si mesma, a vida seguindo a natureza.

[2.7.5b4.1] Portanto, as citadas excelências são <perfeitas $>$, dizem, no que concerne à vida e organizadas através de teoremas ${ }^{66}$; mas há outras adicionadas a essas, não sendo ainda perícias, mas certas capacidades ${ }^{67}$ que resultam de exercício ${ }^{68}$, como saúde da alma, sua sanidade e força, sua beleza.

[2.7.5b4.5] Pois, assim como a saúde do corpo é a moderação do calor, do frio, da secura e da umidade no corpo, do mesmo modo, a <saúde > da alma é a moderação das opinióes na alma.

[2.7.5b4.10] E igualmente, como a força do corpo é o tônus apropriado nos nervos, do mesmo modo, a <força $>$ da alma é o tônus apropriado no julgamento e no agir ou não. Também como a beleza do corpo é a simetria dos lábios, <como são> ordenados em relação um com o outro e também em relação ao todo.

[2.7.5b4.15] Do mesmo modo, a <beleza $>$ da alma é a simetria da razão e das suas partes em relação <ao > todo e também em relação umas com as outras.

[2.7.5b5.1] Mas todas as excelências, na medida em que são conhecimentos e técnicas, possuem teoremas e finalidade em comum, como foi dito, pelo que são <inseparáveis >; pois quem possui uma, possui todas, e quem pratica uma, pratica todas.

[2.7.5b5.5] Mas < diferem> uma da outra, <nas principais [funçóes] >. Pois, primeiramente, as principais [funçóes] $\mathrm{da}<$ prudência $>$ são considerar

\footnotetext{
${ }^{63}$ Télos.

${ }^{64}$ Tó akoloúthōs tếi phýsei zến.

65 "Estabilidade" traduz eustháteia, que pode significar também "tranquilidade". Relativamente ao corpo, significa saúde física.

${ }^{66}$ Theốrema.

${ }^{67}$ Dýnamis.

${ }^{68}$ Áskēsis.
} 
e fazer o que é preciso ser feito, mas, num segundo argumento, considerar o que é preciso repartir, <o que é preciso escolher e o que é preciso tolerar>, [2.7.5b5.10] para, graças <a ela $>$, fazer infalivelmente o que é preciso ser feito. A <função > principal peculiar da <temperança>, primeiramente, é fornecer impulsos estáveis e considerá-los, mas, num segundo argumento, [considerar o que concerne] às outras excelências, de modo que infalivelmente se conduza em seus impulsos.

[2.7.5b5.15] De igual modo, a coragem, primeiramente, é suportar tudo que for preciso, mas, num segundo argumento, <suportar o que concerne > às outras <excelências>; e a <justiça>, primeiramente, é examinar o mérito de cada um, mas, num segundo argumento, é <examinar $>$ o restante. Pois <todas $>$ as excelências veem o que <as concerne $>$ e o que se subordina a todas as outras.

[2.7.5b5.20] Pois Panécio ${ }^{69}$ dizia que o que ocorre com as excelências é o mesmo que se <houvesse> um alvo para muitos arqueiros, nele havendo marcas de diferentes cores. Então, cada arqueiro tentaria acertar o alvo.

[2.7.5b5.25] Um, talvez, lançando <a flecha> em direção à marca branca; outro, lançando <em direção à marca> negra; outro, < lançando a flecha em direção a > uma marca de outra cor. Pois, assim como eles acima de tudo fazem sua finalidade acertar o alvo, mas por cada um $<$ dos arqueiros $>$ são propostos modos bastante diferentes de atingir $\langle 0$ alvo $\rangle$, [2.7.5b5.30], do mesmo modo, <todas $>$ as excelências fazem de sua $<$ finalidade $>$ ser feliz ${ }^{70}$, que é baseada em viver de acordo com a natureza, mas isso <cada uma atinge de modos bastante diferentes>.

[2.7.5b6.1] De dois modos, diz Diógenes ${ }^{71}$, <as coisas são ditas escolhidas $^{72}$ por si mesmas >: tanto <as> que são escolhidas < de modo absoluto $>$, como as ordenadas na supracitada divisão, quanto as que têm nelas $<$ próprias> uma causa (que existe em toda coisa boa) para serem escolhidas.

\footnotetext{
${ }^{69}$ Fragmento 109 (VAN STRAATEN). Panécio de Rhodes viveu entre c. 185 e c. 110/09 a.C. Foi discípulo de Diógenes da Babilônia e de Antípatro de Tarso. Introduziu em Roma o estoicismo, para lá viajando acompanhando seu amigo Cipião Emiliano. Em Roma, permaneceu até à morte deste último, quando voltou para Atenas, onde se tornou o sétimo e último escolarca do Pórtico Ateniense.

70 Eudaimoneîn.

71 Fragmento 48. Diógenes da Babilônia (ou da Seleucia) viveu entre c.230 a.C. e c.150/140 a.C. Em 155, foi enviado em embaixada a Roma, junto como peripatético Critolau e o cético Carnéades. Foi o quinto escolarca do Pórtico Ateniense.
}

72 Hairetá. 
[2.7.5b7.1] Mas as excelências são muitas, dizem, e inseparáveis umas das outras. E elas mesmas <são inseparáveis > da parte diretriz da $\mathrm{alma}^{73}$, de acordo com a substância, pelo que toda excelência é um <corpo $>$, e também $<$ assim> é dita, pois a mente ${ }^{74}$ e a alma ${ }^{75}$ são corpo $<$ s $>{ }^{76}$.

[2.7.5b7.5] Pois o alento ${ }^{77}$ que nos é conato ${ }^{78}$, sendo quente, comanda a alma. Mas desejam que a alma em nós seja viva, pois vive e percebe; e principalmente a parte diretriz dela, que é chamada de mente.

[2.7.5b7.10] Por isso, toda excelência é viva, uma vez que é o mesmo que a mente quanto à essência. Pois, de acordo com isso, dizem que a prudência é prudente, pois falar desse modo é consequência dessas coisas.

[2.7.5b8.1] Mas <entre> a excelência e o vício <nada> há. Pois todos os homens têm por natureza uma inclinação para a excelência, e a têm, como no raciocínio semi-iâmbico ${ }^{79}$ de Cleanto $^{80}$, porque, por um lado, <se> são incompletos, são inúteis, [2.7.5b8.5] mas, por outro lado, se são completos, $<$ são $>$ virtuosos ${ }^{81}$. E dizem que o sábio faz tudo $<$ de acordo com $><$ todas as excelências,> pois cada ação sua é completa, porque não lhe falta nenhuma excelência.

[2.7.5b9.1] Como consequência dessas coisas, opinam que <o sábio $>$ age sensivelmente, <dialeticamente>, <como conviva>, <amorosamente.> Mas <amorosamente> é dito duplamente: por um lado, quanto à excelência, sendo de qualidade virtuosa segundo a excelência; [2.7.5b9.5] por outro lado, segundo o vício, na censura, como alguém que estivesse enlouquecido por

\footnotetext{
${ }^{73} \mathrm{O}$ hégemonikón. De acordo com a doutrina ortodoxa estoica, a alma possui oito funçôes: a faculdade diretriz, os cinco sentidos, a voz e a função reprodutiva. Entretanto, todas estas sete últimas são extensóes daquela, que está para a cabeça de um polvo assim como seus tentáculos estáo para as demais funçôes.

${ }^{74}$ Diánoia. Ou "pensamento".

${ }^{75}$ Psyché.

${ }^{76}$ Sồma.

${ }^{77}$ Noûs.

${ }^{78}$ Symphyés.

${ }^{79}$ Pomeroy (1999, p. 109, n. 38) observa que há referência, nesse ponto, aos versos que devem ser declamados ininterruptamente numa peça teatral, os quais, se não o forem, ficam carecendo de sentido, tornando-se, portanto, "inúteis". Cf. ARISTÓFANES, As Nuvens, 1449-1452.

${ }^{80}$ Cleanto de Assos, originário da Ásia Menor, viveu entre c. 330 a.C e c.230 a.C. Sucedeu Zenão, tornando-se o segundo escolarca do Pórtico.
}

81 "Virtuoso" traduz aqui spoudaîos, que significa também "grave, sério, bom, virtuoso". 
amor. É o amor <a amizade pelo que é virtuoso >. Fala-se igualmente de quem é mais digno de amor e de quem é mais digno de amizade, pois quem é mais digno do amor virtuoso é o que é mais digno do amor.

[2.7.5b9.10] Do mesmo modo que com <a [excelência] amorosa>, entre as excelências admitem a <convival>, acerca do que é conveniente em um banquete, o conhecimento de como é preciso conduzir um banquete e como é preciso beber acompanhado; a seguir, é o conhecimento da caça por jovens naturalmente capazes, exortando-os para o que está de acordo com a excelência e, em geral, para o conhecimento de amar belamente (SVF III.719).

[2.7.5b9.15] E por isso dizem que quem tem inteligência ${ }^{82}$ amará. $<$ Mas amar> por si só é somente indiferente, uma vez que amiúde ocorre entre $<$ homens > inúteis. Mas o amor nem é um apetite ${ }^{83}$, nem uma coisa inútil, mas uma inclinação ${ }^{84}$ para fazer amigos a partir da impressão da beleza.

[2.7.5b10.1] Dizem que <tudo> o que o <sábio > faz, faz <bem>. Evidente. Pois, [do mesmo] modo que dizemos que faz tudo bem o tocador de flauta ou o tocador de cítara, entendendo com isso o que, por um lado, concerne à arte do flautista e, por outro lado, à arte do citarista [2.7.5b10.5], do mesmo modo, o prudente todas as coisas faz bem - e as quantas coisas que faz (não, por Zeus, também as que não faz). Pois perfaz todas as coisas segundo a reta razáo e de modo segundo a excelência, sendo a arte de viver acerca do todo, do que creem <ser> consequência a opinião <segundo a qual> o sábio age bem acerca de tudo.

[2.7.5b10.10] Analogamente, o medíocre faz mal e de acordo com todos os vícios tudo o que faz.

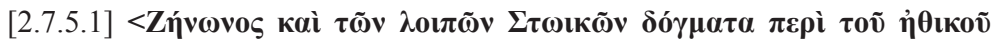

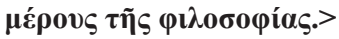

\footnotetext{
${ }^{82}$ Noûs.

${ }^{83}$ Epithymía.

${ }^{84}$ Epibolé.
} 


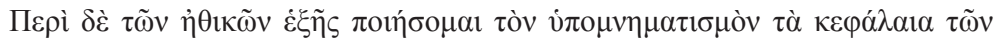

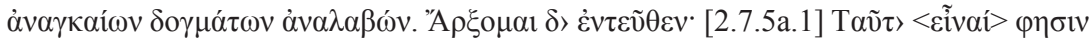

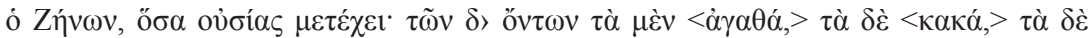

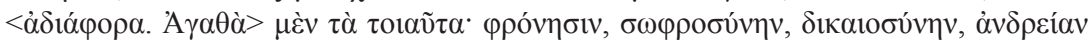

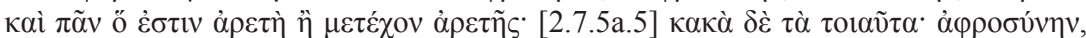

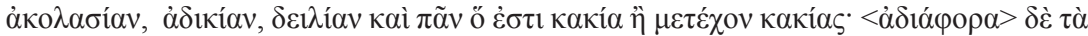

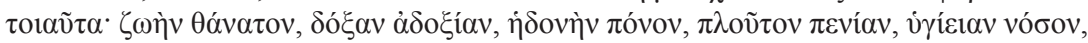

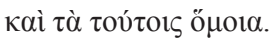

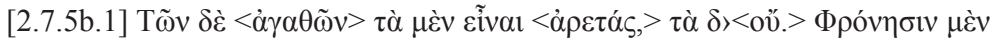

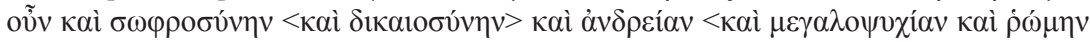

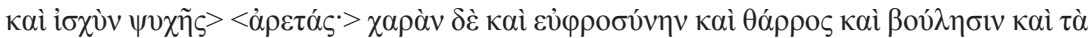

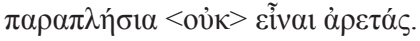

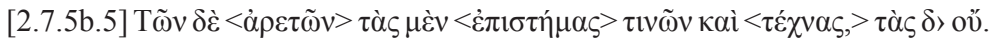

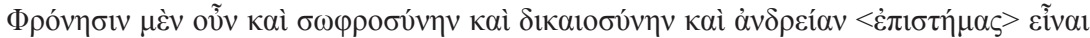

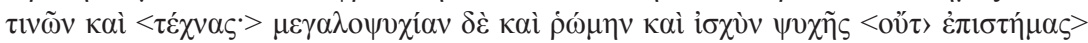

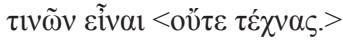

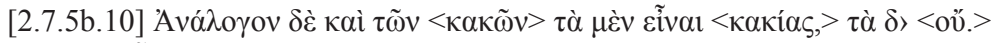

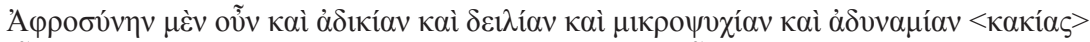

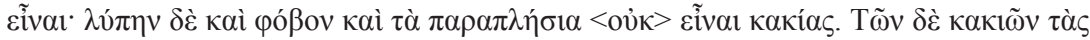

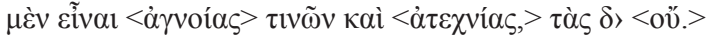

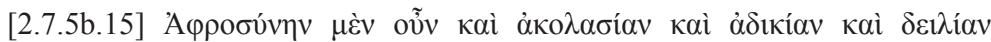

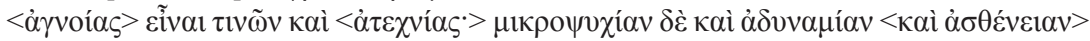

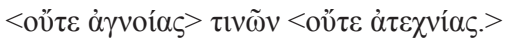

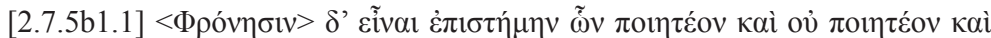

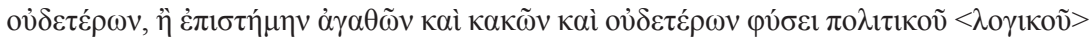

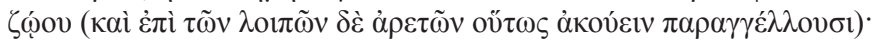

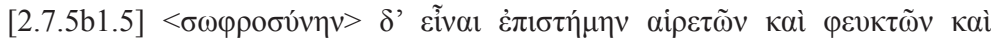

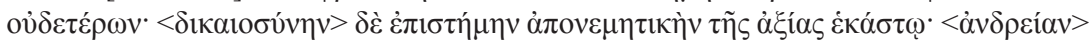

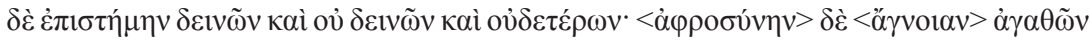

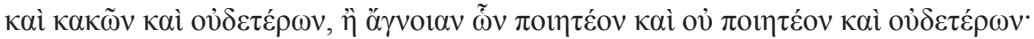

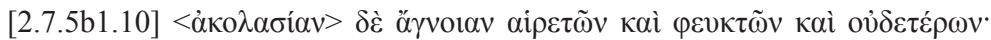

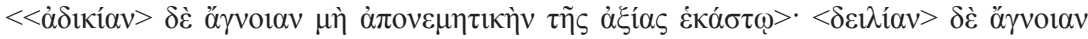

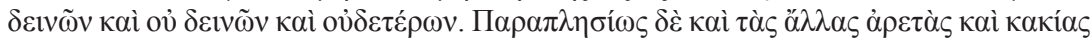

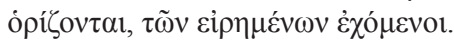

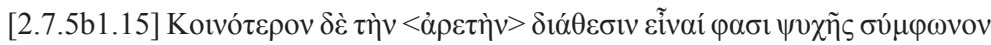

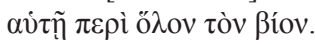

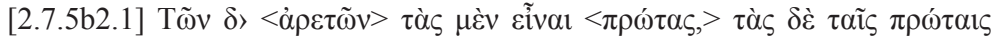

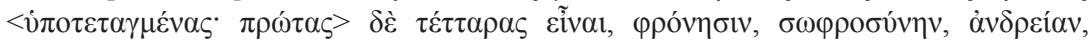




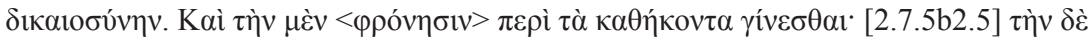

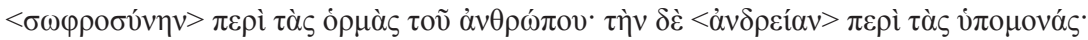

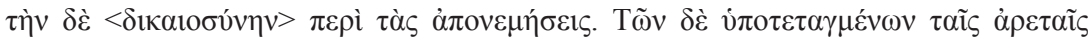

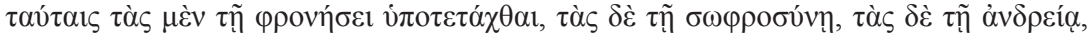

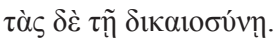

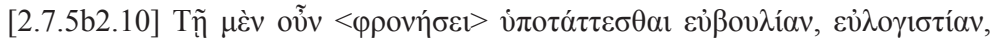

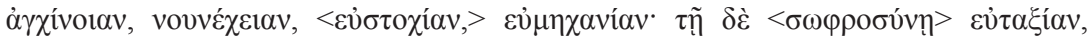

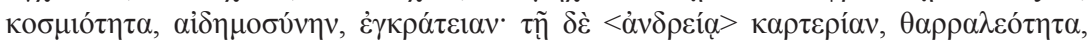

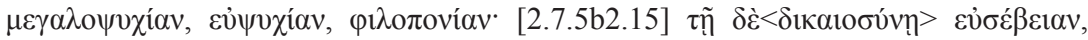

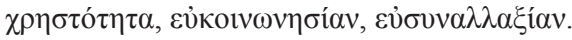

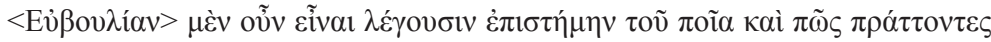

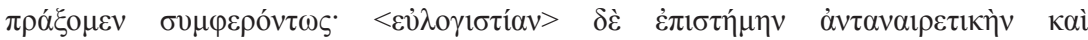

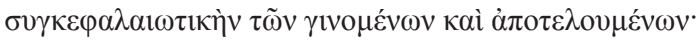

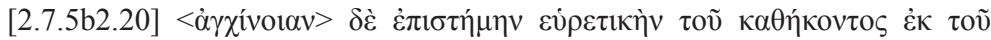

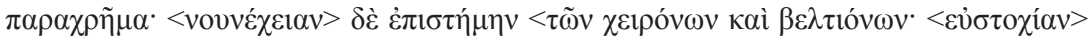

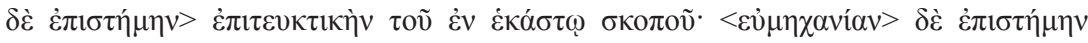

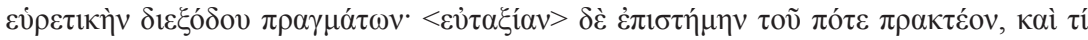

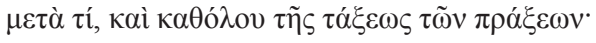

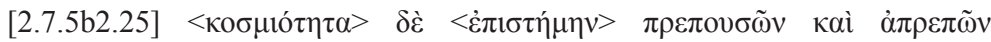

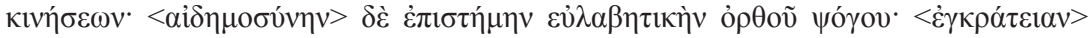

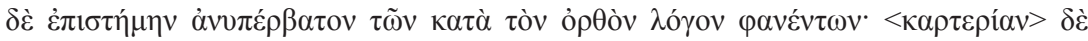

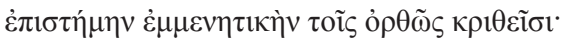

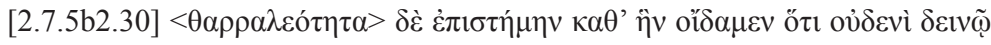

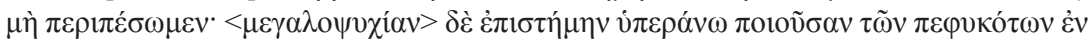

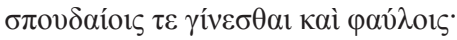

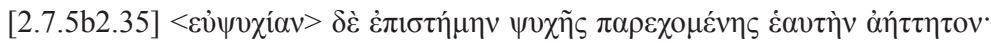

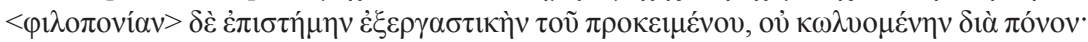

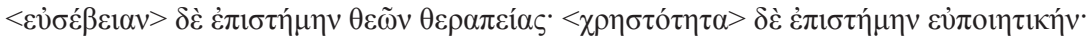

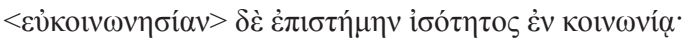

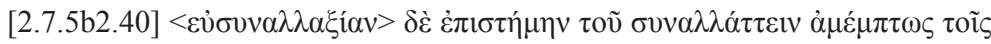
$\pi \lambda \eta \sigma i ́ o v$.

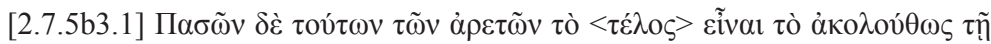

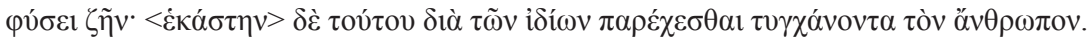

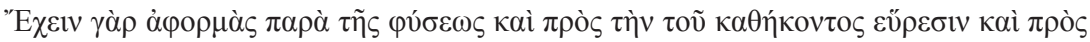

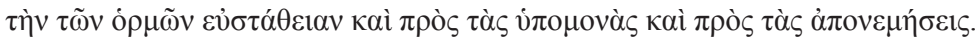

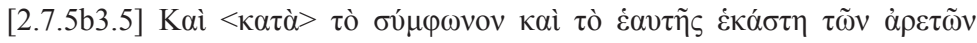

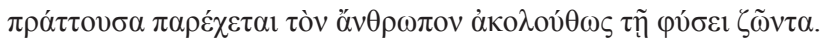

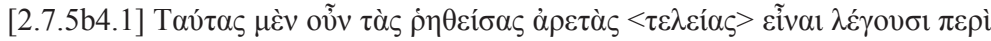

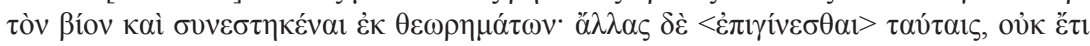




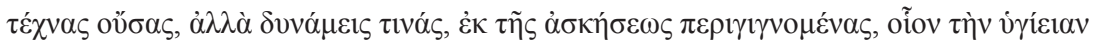

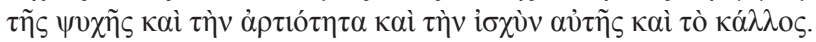

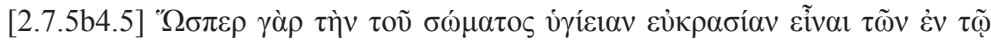

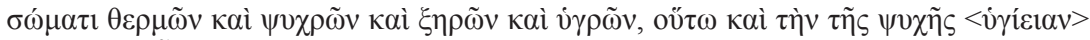

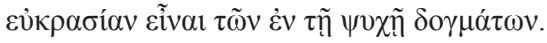

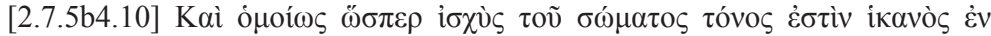

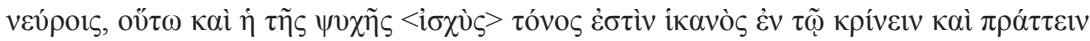

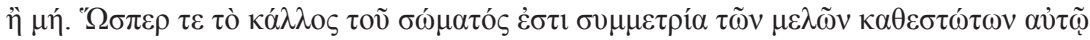

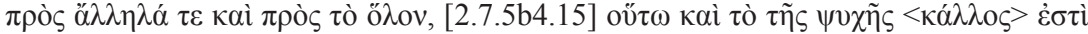

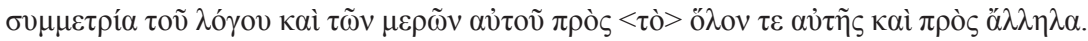

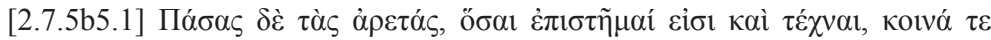

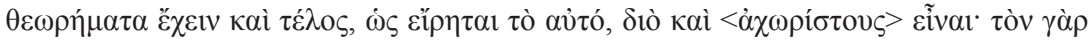

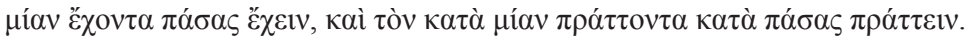

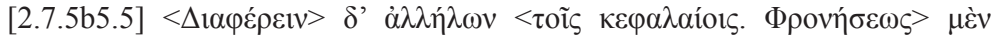

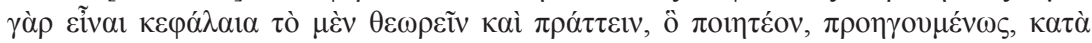

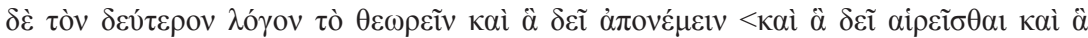

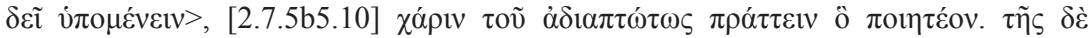

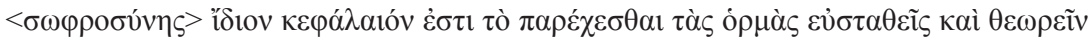

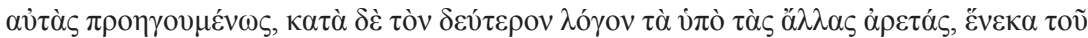

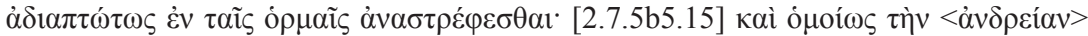

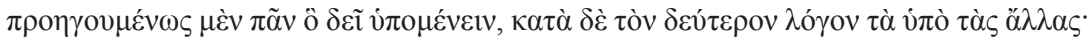

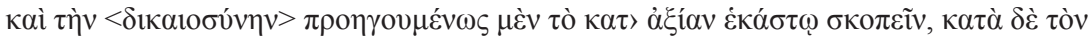

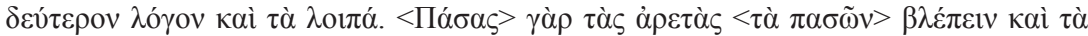
نं

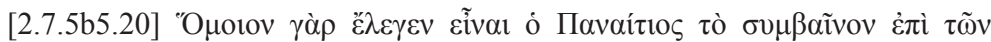

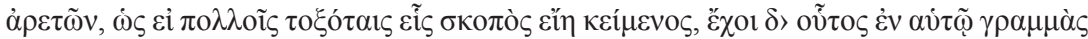

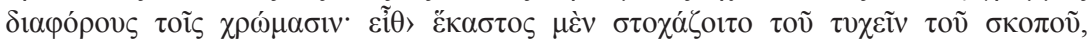

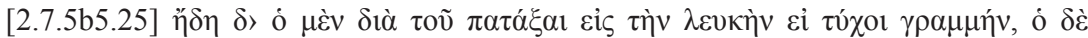

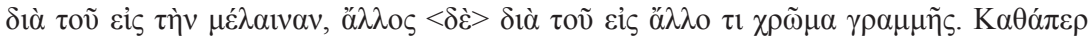

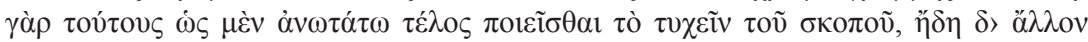

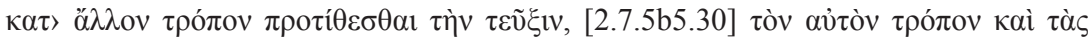

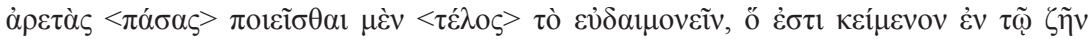

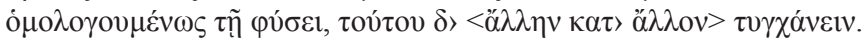

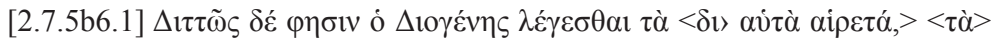

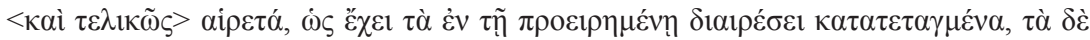

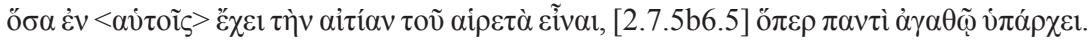

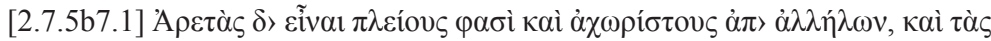

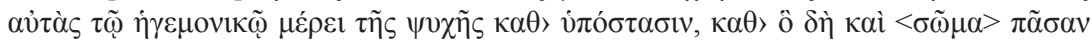

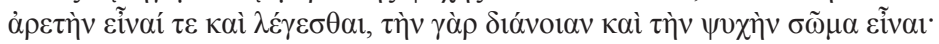




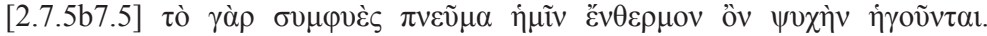

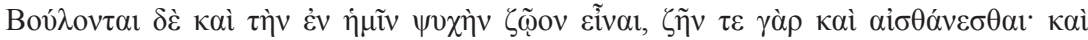

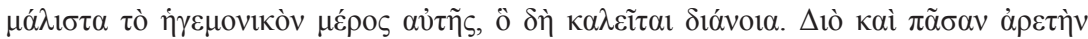

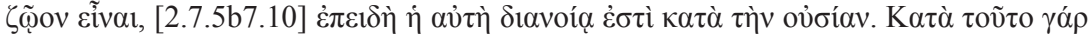

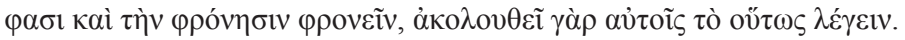

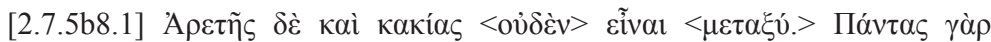

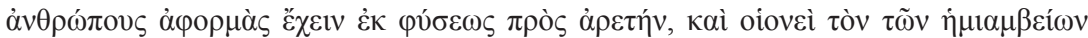

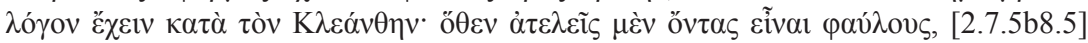

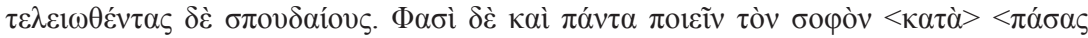

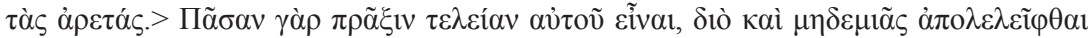

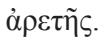

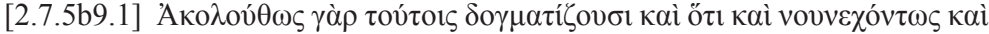

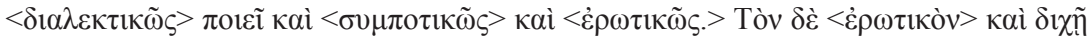

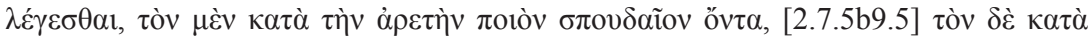

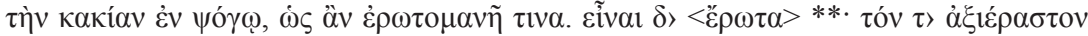

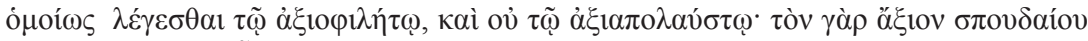

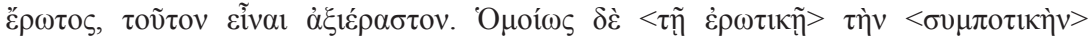

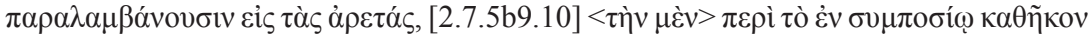

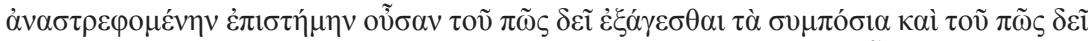

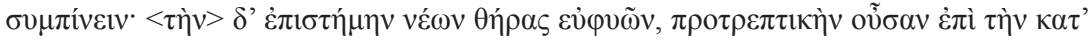

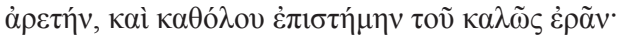

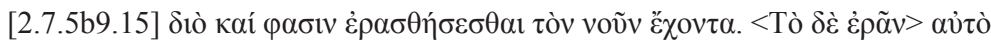

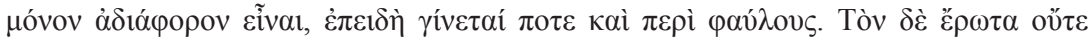

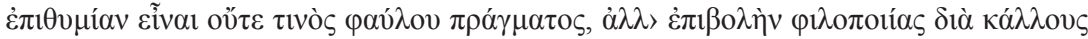
$\ddot{\varepsilon} \mu \varphi \alpha \sigma \mathrm{v}$.

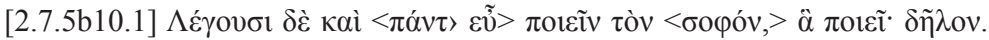

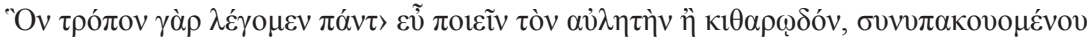

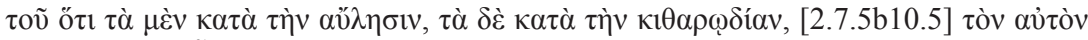

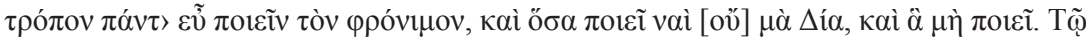

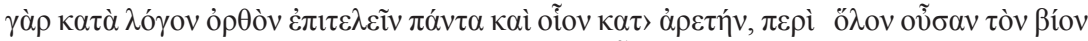

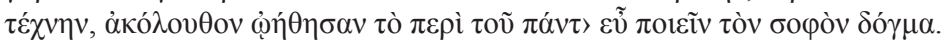

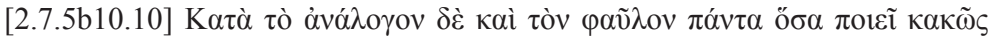

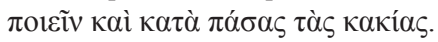


BRITO, Rodrigo Pinto; DINUCCI, Aldo. Translation: Epitome of Stoic Ethics, 2.7.5A2.7.5B. Trans/form/ação, Marília, v. 39, n. 2, p. 255-274, Abr./Jun., 2016.

ABSTRACT: Translation of 2.7.5A- 2.7.5B of the Epitome of Stoic Ethics by the Stoic philosopher and Alexandrian doxographer Arius Didymus (fl. $30 \mathrm{BC}$ ). There are no translations of Arius Didymus' complete works into modern languages. Thus for this translation we utilized Pomeroy's fixation of the exposition of Stoic ethics found in Stobaeus' Florilegium (1999). Parts 2.7.5A- 2.7.5B deal with the Stoic concept of excellence, explaining what excellence is, what virtues participate in it, and how. Arius Didymus also explains the Stoic concept of vice, what it is, and its taxonomy.

KEYWORDS: Hellenistic philosophy, Stoic ethics, Arius Didymus, translation.

\section{REFERÊNCIAS}

ÁRIO DÍDIMO. Epitome of stoic ethics. Tradução de Arthur J. Pomeroy. Atlanta: Society of Biblical Literature, 1999.

ARISTÓFANES. Clouds. Wasps. Peace. Tradução de J. Henderson. Harvard: Loeb Classical Library, 1998.

CÍCERO. On ends (The Finibus). Tradução de H. Rackham. Harvard: Loeb Classical Library, 1914.

CLEMENTE DE ALEXANDRIA. Miscellanies (Stromata). Memphis: Bottom of the Hill, 2012.

DIELS, H. Doxographi Graeci. Berlim: Berolini, 1879.

DIÓGENES LAÉRCIO. Lives of eminent philosophers. Tradução de R. D. Hicks. Harvard: Loeb, 1925.

DION CÁSSIO. Roman history. Tradução de Cary Foster. Harvard: Loeb Classical Library, 1914-1927.

ESTOBEU. Florilegium, v. I e II. Ed. Augustus Meineke. Lipsiae: Taubner, 1855.

EUSÉBIO DE CESAREIA. Praeparatio evangelica. Tradução Gifford. Oxford: Clarendon Press, 1903.

FRASER, P. M. Ptolemaic Alexandria. Oxford: Clarendon Press, 1972.

GIUSTA, M. I dossografi di etica. Torino: Giappi-Chelli, 1964-1967. 2 v.

GLUCKER, C. Antiochus and the later academy. Gotingen: Vandenhoeck \& Ruprecht, 1978.

GÖRANNSSON, T. Albinus, Alcinous, Arius Dydimus. Acta Unversalis Othburgensis, p. 203-218, 1995. 
HAHM, D. E. The ethical doxography of Arius Didymus. $A N R W$, II, v. 36 n.4, p. 29353055, 1990.

INWOOD, B. B. GÖRANSSON, T. Albinus, Alcinous, Arius Didymus (review). In: Bryn Mawr Classical Review 95.12.8, 1995a. p.257. (online = 7, p. 25-30, 1996).

. Ethics and human action in early stoicism. Oxford: Clarendon Press, 1995 b.

IOPPOLO, A. M. Il Monismo psicologico degli Stoici antichi. Elenchos, v. 8, p. 449-466, 1987.

JULIANO. Letters, Tradução de Wilmer C. Wright. Oxford: Loeb, 1923. 3v.

LONG, A. Arius Didymus and the exposition of stoic ethics. In: FORTENBAUGH, W. W. (Ed.). On stoic and Peripatetic ethics: the work of Arius Didymus. London: Transaction, 1983. p. 190-201.

MEINEKE, A. Zu Stobaeus. Zeitschrift für Gymnasialwesen, v. 13, p. 363-365, 1859.

PANÉCIO DE RHODES. Panaetius, sa vie, ses écrits et sa doctrine. Avec une édition des fragments. Organização M. Van Straaten, M. Amsterdam; Paris, 1946.

PLATÃO. Laches. Protagoras. Meno. Euthydemus. Tradução de W. R. M. Lamb. Harvard: Loeb Classical Library, 1924.

V. $1-2$.

Republic, Tradução de P. Shorey. Harvard: Loeb Classical Library, 1930-1935.

PLUTARCO. Life of Antonius. Oxford: Loeb, 1920.

. Moralia: stoic essays. Tradução H. Cherniss. Harvard: Loeb, 1976. V. 13, part 2.

SÊNECA. Epistles 1-66. Tradução de R. M. Gummere. Harvard: Loeb Classical Library, 2001.

2001.

Epistles 66-92. Tradução de R. M. Gummere. Harvard: Loeb Classical Library, . Moral essas. Tradução de J. W. Basore. Harvard: Loeb Classical Library, 2001. V. 2. . Moral essays. Tradução de J. W. Basore. Harvard: Loeb Classical Library, 2001.

V. 3 .

SUETÔNIO. Lives of the Caesars. Tradução de J. C. Rolfe. Harvard: Loeb Classical Library, 1914. V. 1-2.

VON ARNIM, H. Stoicorum veterum fragmenta: Zeno or Zenonis discipuli [1903]. Berlim: De Gruyter, 2005. V. 1.

Stoicorum veterum fragmenta: Chrysippi fragmenta logica et physica [1903]. Berlim: De Gruyter, 2005. V. 2.

- Stoicorum veterum fragmenta: Chrysippi fragmenta moralia: fragmenta successorum Chrysippi [1903]. Berlim: De Gruyter, 2005. V. 3. 
BRITO, R. P.; DINUCCI, A.

Stoicorum veterum fragmenta: Indeces [1905]. Berlim: De Gruyter, 2005. V. 4.

XENOFONTE. Memorabilia. oeconomicus. symposium. Apology. Tradução de E. C. Marchant; O. J. Todd. Harvard: Loeb Classical Library, 1923.

Recebido em 20/12/2015

Aceito em 07/03/2016 